\title{
Intermédialités
}

Histoire et théorie des arts, des lettres et des techniques

Intermediality

History and Theory of the Arts, Literature and Technologies

\section{In the University's Ruins, Some Audiovisual Thoughts}

\section{Laura U. Marks}

Numéro 5, printemps 2005

Transmettre

Transmitting

URI : https://id.erudit.org/iderudit/1005498ar

DOI : https://doi.org/10.7202/1005498ar

Aller au sommaire du numéro

\section{Éditeur(s)}

Centre de recherche sur l'intermédialité

ISSN

1705-8546 (imprimé)

1920-3136 (numérique)

Découvrir la revue

Citer cet article

Marks, L. U. (2005). In the University's Ruins, Some Audiovisual Thoughts. Intermédialités / Intermediality, (5), 173-189. https://doi.org/10.7202/1005498ar

\section{Résumé de l'article}

Les productions intellectuelles à l'université sont de plus en plus en plus en mesure d'incorporer des formes multiples d'intelligence, telle que l'acuité visuelle, l'intelligence corporelle, et la capacité de faire des sauts logiques relevant de l'abduction. Toutefois, la connaissance universitaire est de plus en plus rattachée à une valeur instrumentale; en effet, les universités sont déjà en train d'incorporer l'" audiovisuel » comme une ressource intellectuelle et une marchandise. Dans les ruines des valeurs (la raison, la culture, l'excellence) sur lesquelles, historiquement, les universités ont été bâties (selon Bill Readings), une pédagogie créatrice ralentit le processus par lequel l'expérience est immédiatement traduite en signification, la signification en communication, et la communication en marchandise. Ces idées sont élaborées en partant de l'expérience d'un cours que l'auteur a développé, qui avait pour titre "Audiovisual Practice». 


\title{
In the University's Ruins, Some Audiovisual Thoughts
}

\author{
Laura U. Marks
}

T he film studies undergraduates were disaffected and restless. They'd joined the program because they loved movies and wanted to make them, but instead they were writing essay after analytical essay. They were sick of writing, but they weren't quitting to go to film school.

The students' inchoate yearning got me thinking. Here were people who had grown up in audiovisual worlds, more than we, their teachers, had. Did they have some abilities, which the generations of their professors lacked, that should be recognized as part of their studies? Or were they just subjects of an audiovisual culture in which language becomes dangerously conflated with image? I came to believe a third possibility, that living in audiovisual culture stimulated potential knowledges, in this generation that could just make them better media consumers, or it could be used creatively. And I suspected a fourth: that their embodied not-quite-knowledges, would be the source of their most significant-even if meaningless-discoveries.

This essay will suggest ways that intellectual production in the university can incorporate intelligences that are currently not cultivated outside fine art and creative writing programs: for example, visual acuity, bodily intelligence, and the ability to make abductive leaps. Many humanities scholars are already moving beyond the written essay form, producing modestly audiovisual work in the form of interactive, illustrated essays in online journals. But I suggest that the most promising forms of non-written intelligence are those that don't necessarily incorporate the new information media but that explore the communicative qualities of embodied, "irrational," or relatively nondiscursive kinds of knowledge. I designed a course called "Audiovisual Practice," in which students in a scholarly (not artistic) program produced "smart" audiovisual objects such as videos, websites, and performances. The course was thick with lessons, for 
the teacher, in the possibilities of doing intellectual work in audiovisual form. They ultimately suggested that the most valuable learning experiences are those whose meaning is not readily translatable; those which linger in the university's ruins, in the phrase of the late Bill Readings, ${ }^{1}$ rather than speedily convert audiovisual expression into a new marketable university product.

\section{The Place of the Audiovisual in the University of Reason}

My first hunch that intellectual work could be produced in non-verbal, audiovisual forms came from the artists' films and videos that are my own object of study. These are works that don't ask to be analyzed as much as listened to. They have a special kind of intelligence that is rational, poetic, visual, sonic, rhythmic, and in other ways invites the beholder to respond to them with an embodied intelligence. It has always seemed to me that art gets hold of things that matter in the world a generation or so before scholarship catches up. I wanted to close the gap. Our method would no longer be words alone, but audiovisual images, which might include words. Our object would no longer be only images, but the world itself. I proposed to do philosophy audiovisually.

The film studies program at Carleton University had no place for courses in film production. Like many film studies departments, it had been founded on the principles, once radical, that film studies is a discipline in its own right, it has its own object of study and analytical approaches, and its discourse is rational. Production courses were opposed on two bases: they did not form part of the discourse of the discipline, and they belonged to professional, not scholarly, education.

My colleagues, like many other cinema scholars, were defending a particular notion, or two particular notions, of what a university education should be. In The University in Ruins, Readings argues that the modern university has been redefined around successive central ideas: reason, culture, and "excellence." The first has Kantian roots: the task of each discipline is to refine itself through rational self-criticism. ${ }^{2}$ In some ways my program, with its continued emphasis on defining the object of film studies and the methodologies appropriate to it, was upholding a Kantian notion of the university. The Romantic discourse of

1. Bill Readings, The University in Ruins, Cambridge, Massachusetts, London, Harvard University Press, 1996.

2. Bill Readings, The University in Ruins, p. 56-58. 
culture animated the curriculum as well, for example in the debate over the canon of cinematic works: what culture must a student own in order to be a good citizen. ${ }^{3}$

More importantly, both the University of Reason and that of Culture aspire to produce critical subjects, who would then be able to participate responsibly in the life of the nation. We all want to teach students to think critically. While I shared with my colleagues the goal of producing critical subjects, the means with which I proposed to do this appeared irrational to them. The University of Reason fears that non-verbal forms cannot be a part of rational discourse. How can moving images, dance, performance, sound and color, smell, and other such media tell in a way that can be accepted in the discourse of the academy?

One answer might be that these forms can be understood as rhetoric. They attempt to persuade listeners by appealing to emotions, and to the body. They are rationality clothed in irrationality. Yet, as Bill Nichols writes, this hierarchy disguises a power relationship whereby only those at the center of power appear to speak rationally. Everybody else must resort to rhetoric, which only appears as excess to reason. By privileging the honesty of rhetoric over the falsity of reason, Nichols proposes to re-center the power of the speaker. ${ }^{4}$ Rhetoric, or thought grounded in subjectivity, questions the means of communication, while persisting in the effort to communicate.

Another answer profits from evidence that there are intelligences that the university does not reward and nurture, but it could. Howard Gardner's theory of multiple intelligences is useful in this regard. A psychologist, Gardner defines his categories of intelligence according to fairly rigorous criteria from the biological (they are localized in particular areas of the brain; they have evolved with humans) to the logical (they have an identifiable set of core operations). ${ }^{5}$ Of Gardner's seven to nine categories of intelligence, it is clear that the university rewards only two, the linguistic and the logical. Other intelligences, such as musical, spatial, interpersonal, and the controversial existential intelligence, ${ }^{6}$

3. Bill Readings, The University in Ruins, p. 63-67.

4. Bill Nichols, "Film and the Uses of Rhetoric," Society for Cinema Studies Conference, San Diego, California, 1998.

5. Howard Gardner, Intelligence Reframed: Multiple Intelligences for the 21st Century, New York, Basic Books, 1999, p. 36-40.

6. Howard Gardner, Intelligence Reframed, p. 41-44; p. 6o-66. 
are not recognized by the university. The ability of some students to respond with acute awareness to music, for example, even if they couldn't parse a sentence, signals intelligence waiting to be acknowledged. The present system could not deal with their capacities for creating and comprehending non-linguistic signification.

After the restlessness of the students, the critical potential of art, and the possibility that there are other kinds of intelligence to nurture, a fourth goad to developing an audiovisual intellectual practice was negative: the suspicion that scholars' verbal tools no longer function to analyze the increasingly audiovisual world of Western, postindustrial capitalism. Images are getting "smarter" than us. The Frankfurt School critics had suspected this decades earlier, and responded in a variety of ways, from Theodor Adorno's profound suspicion of the audiovisual world ${ }^{7}$ to the troubled yearning of Walter Benjamin, who felt the seduction of this world even as he understood it as fundamentally corrupted by capitalism. Benjamin modeled his writing in the Arcades Project on the cinema: a montage of original and quoted texts, such that none claimed authority but a dialectic emerged from them, somewhere beyond the author's control. Benjamin's purpose in the Arcades project was to see the world in the fragment ("the ruffle of a dress"); in particular, to achieve a historical and economic analysis through the dialectics of the image. ${ }^{8}$ Benjamin's technique is of course a verbal one, but it respects the complexity of the image and elicits an acute attention to images, small events that crystallize a socioeconomic whole.

Benjamin was developing this technique of the dialectical image in order finally to arrive at an analysis of the nineteenth-century: the Parisian shopping arcades that gave his massive, incomplete work its title were already in ruins. In the twenty-first century, to think like Benjamin we cannot perform image dialectics, or at least we cannot stop there; for the advertising industry, populated by smart dropouts from semiotics, is doing it too. Noting that Marx wrote that "the last stage of a world-historical form is its comedy [.... so that mankind may

7. On the concept of art as negation, see for example Max Horkheimer and Theodor W. Adorno, Dialectic of Enlightenment, trans. John Cumming, New York, Herder and Herder, 1972 [1944], p. 129-133, and Theodor W. Adorno, Prisms, trans. Samuel and Shierry Weber, London, Spearman Press, 1967 [1955], p. 32.

8. Walter Benjamin, "N [On the Theory of Knowledge, Theory of Progress]," The Arcades Project, trans. Howard Eiland and Kevin McLaughlin, Cambridge, Massachusetts, London, Belknap Press of Harvard University Press, 1999 [1927-1940], p. 461-463. 


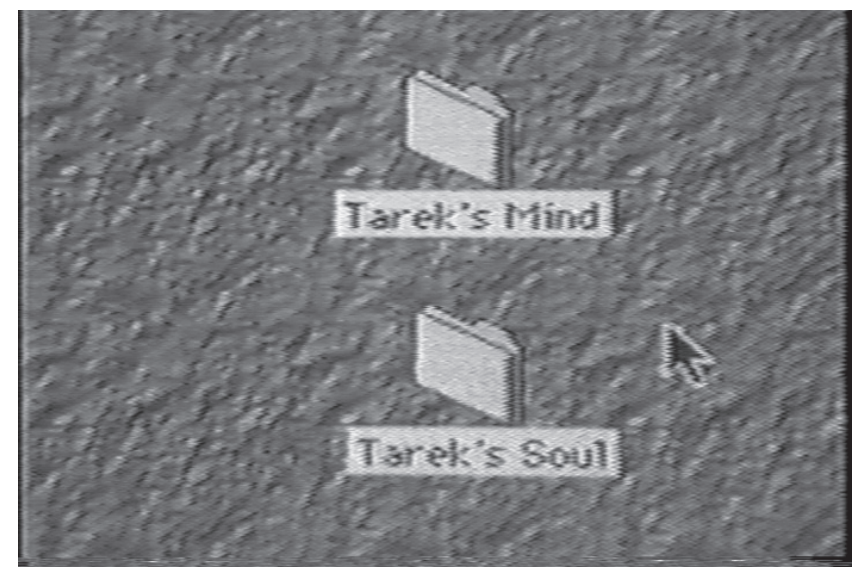

Fig. 1. Still from Translations (2001) by Tarek Al-Zand.

take leave of its past gaily," Benjamin suggested that Surrealism was the comic leave-taking of the nineteenth-century. ${ }^{9}$ What might be the dialectical technique for the late twentieth and early twenty-first centuries?

The answer cannot lie in images alone. The media environment in which we, in post-industrial countries, live is audiovisually saturated but, nevertheless, symbolic. It is audiovisual in the most impoverished way: its thick mesh of images and sounds reduce quickly to signs, information, and ultimately, money. We who live in the world's well-lined pockets inhabit "the audiovisual," D. N. Rodowick's term for a discursive regime in which word and audiovisual image dissolve into one another. "Expression is no longer reserved for linguistic activity which organizes 'signs' and therefore meaning across difference; the field of the visible, as the silent representation of things, has become increasingly heterogeneous and complex." ${ }^{10}$ In such a culture, images are not dialectical. Surrealism, montage, appropriation and all the other modernist techniques for analyzing the image-skin of nineteenth-century capitalist society have been wrung dry by the image-eating society of contemporary capitalism. Replacing words with audiovisual images does not guarantee an outflow of new knowledge.

9. Walter Benjamin, "N," p. 467.

10. David N. Rodowick, "Audiovisual Culture and Interdisciplinary Knowledge," New Literary History, Vol. 26, No. 1, Winter, 1995, p. 111-121. 
Rodowick defines audiovisual culture as the culture of a new historical era in which investment by global communications companies is driving the so-called convergence of audiovisual media. His emphasis on the economic nature of this shift insists that audiovisual culture is inextricable from global financial power. Yet I think Rodowick exaggerates: it's not audiovisual media themselves but how they are deployed that enters them into the culture of global capitalism. It is new that digital tools make it "easy" for people to produce audiovisual images and, at the same time, pull us into a commodity discourse. This conflation of intellectual resource and commodity in the digital media explains why so many university departments that never had film/video production are suddenly cultivating courses in digital media production. But audiovisual intellectual discourse itself predates digital media; it is a long-standing critical practice that I hesitantly date to the beginnings of modernism.

If they are to Think, audiovisual images cannot be so easily reducible. To be truly pedagogical, that is, to truly encourage the issue of new thoughts, audiovisual work must trouble the production of meaning. What can intervene dialectically in audiovisual culture is not other images in themselves, but interruptions on the social and economic level. Most powerful among these, as I will suggest in conclusion, are refusals to enter into the economy of value.

Yet, because the university lags so far behind, honorably refusing to believe that reason is no longer its raison d'etre, perhaps some of those techniques have a shock value within this institution that they lack outside. So the course would use modernist audiovisual techniques to produce its intellectual objects: shock one. Shock two: if Surrealism was the comic death of the nineteenth-century, maybe a useless, regressive, dangerous course of study would be the comic demise of our twentieth-century university.

\section{Stone Soup}

At one point I conceived that "Audiovisual Practice" would help students understand cinema better by learning the material process of cinema production, from shooting to montage to preparing a budget and applying for funding. This is a time-honored function of production courses in film studies programs. But my approach became more ambitious and more conceptual: to explore cinema as a medium of thought. We would look at cinematic practices that suggested certain arguments or intellectual approaches: for example, montage with Eisenstein; the diary film with feminism; films emphasizing the act of vision with theories of visuality; appropriation with Foucault's dictum, "What we see 


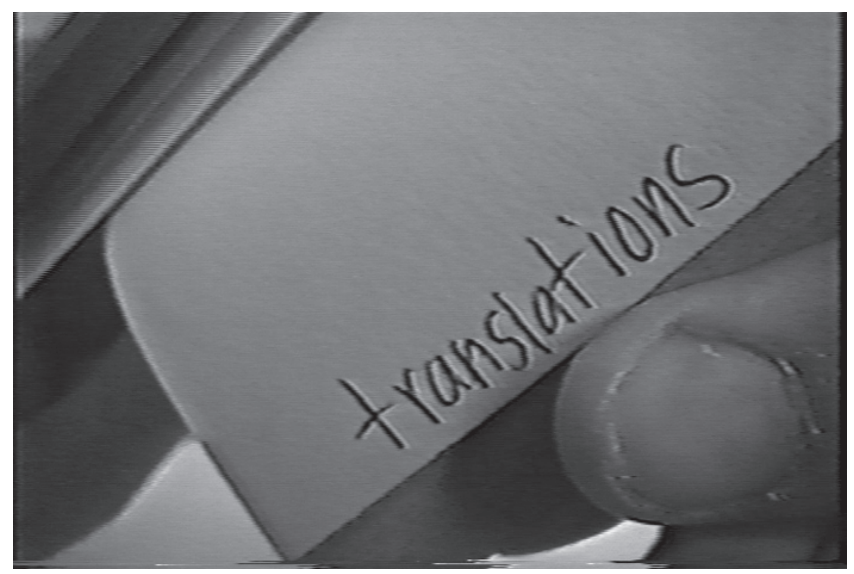

Fig. 2. Still from Translations (2001) by Tarek Al-Zand.

never lies in what we say, and vice versa." It was this focus that convinced my colleagues, who had successfully resisted the introduction of production courses for years, to approve the introduction of "Audiovisual Practice."

The next hurdle was to figure out what kind of works we would produce in the course, and how, given that there was no equipment in the department. In the tale of "Stone Soup," a woman knocks on doors in the village inviting people to share her pot of stone soup. They laugh, "Soup from a stone! Impossible." She says, "It is possible, I have it right here, though of course if I had some onions. . . some barley. . . a beef bone, it would be more delicious." The skeptical villagers contribute ingredients until, surprise, there is enough tasty stone soup for everybody. Audiovisual Practice was like stone soup. In the spirit of Stan Brakhage's A Moving Picture Giving and Taking Book, ${ }^{11} \mathrm{I}$ accepted that one could do many things with film before one actually needed a camera. In my department there was not no equipment: there were VCRs, audiocassette and CD players, erased videotapes, various cables, slide projectors, some trashed $16 \mathrm{~mm}$ films, and a splicer. Already quite a lot. Then I approached the programs on campus that had audiovisual production equipment: architecture and journalism, which require video as part of professional training.

11. Stan Brakhage, A Moving Picture Giving and Taking Book, West Newbury, Frontier Press, 1971. 
Of course nobody wanted to contribute their hard-won resources to my pot of stones. Journalism students paid extra tuition for access to media production equipment. But the journalism department permitted us to use the 12-year-old Hi8 cameras, and the linear video editing suite, that it was de-accessioning. The campus wide instructional media service kindly agreed to provide technical support. Some students had their own Super 8 cameras. I learned a few skills so that I could teach them to the students: how to edit using two VCRs; how to clean film stock, draw on it, and splice it together; how to build simple websites. Thus in the end we had a raft of production means: the ancient cameras; cumbersome analog editing or, the choice of more students, editing in-camera or using two VCRs; sound tracks on audiotape or CDs; slide projectors (the "poor man's AVID”), photos, writing. For inspiration we watched lowbudget works: single-shot films, found and appropriated footage, photo series, works made with consumer and toy video cameras. ${ }^{12}$

The resulting projects had a raw, fierce energy. SAW Video Co-op, Ottawa's artist-run centre for video, hosted our first end-of-semester screening, with paid projectionists who were themselves low-budget experimental filmmakers. The event went on for four hours, in extreme heat and a chaos of multiple formats, to an audience of 100. The room pulsed with exhilaration, laughter, shock, and a tender respect for the work. Their makers had labored over them for countless hours (sometimes to the neglect of their other schoolwork) and the results were sometimes technical failures, sometimes great surprises, sometimes so intimate that a hush would descend upon the sweating crowd.

I describe the technical infrastructure of the course in such detail because it diagnoses a productive tension within the university. In making use of the deaccessioned video equipment from a professional program and using film studies' equipment for purposes other than the screenings and repairs for which it was intended, we were enacting what Readings calls an institutional détoumement. We were taking up the scraps of the university of excellence, i.e. the discarded equipment of Carleton's award-winning journalism department, and using them to a purpose that was not excellent. "Dwelling in the ruins of the university," Readings writes, "means giving a serious attention to the complexity of its space, undertaking an endless work of détournement of the spaces willed to us by a history we no longer inhabit."13

12. Stills from two student projects for the course, Look at Me (1998) by Petek Berksoy and Translations (2001) by Tarek Al-Zand, accompany this essay.

13. Bill Readings, The University in Ruins, p. 129. 


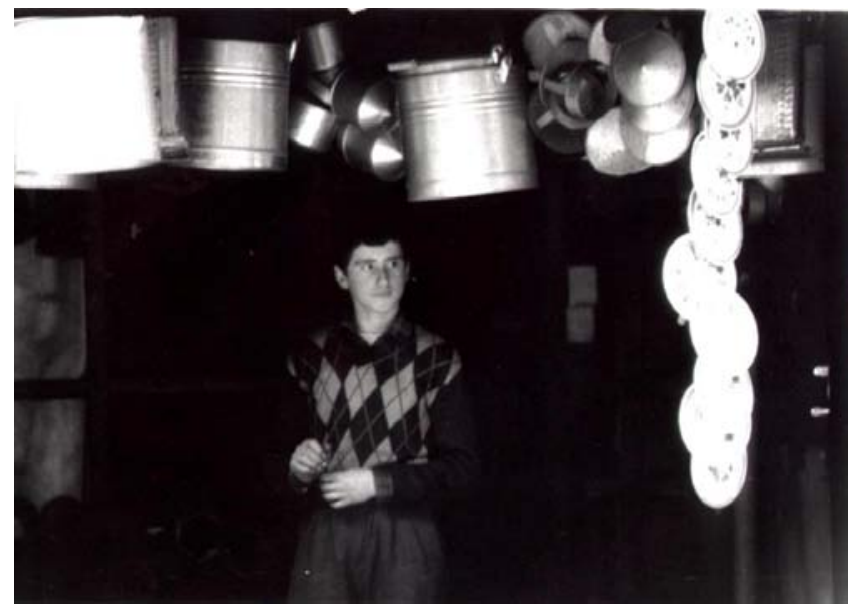

Fig. 3. Still from Look at me (1998) by Petek Berksoy.

\section{Learning From Audiovisual Practice}

My journal over the three years I taught $\mathrm{A} / \mathrm{V}$ (as students called it) is full of accounts of coming home drained and delirious after another intense, exhausting class. We were present at the birth of Thought: absorbing conversations, thrilling arguments, beautiful moments where everybody is thinking about the same problem, sophisticated aesthetic and political discussions, moments of painful awkwardness. Much of the power of the course came from the personal nature of the work we were doing. I was not exempt; indeed I felt that if the students were required to reveal their creativity and, often, their personal history, I should be too. If I asked them to make collaborative projects, I should collaborate as well. Yet as the professor, I had to retain some authority and not treat it as an uninflected two-way flow. As Readings argues, the goal of reflexive pedagogy is not to defer to students but to uphold a goal of communicative struggle beyond us. ${ }^{14}$ It was difficult to determine the balance; many times I went "too far," but these pedagogical tensions were also some of the most fruitful moments in the course.

14. Bill Readings, The University in Ruins, p. 162-163. 


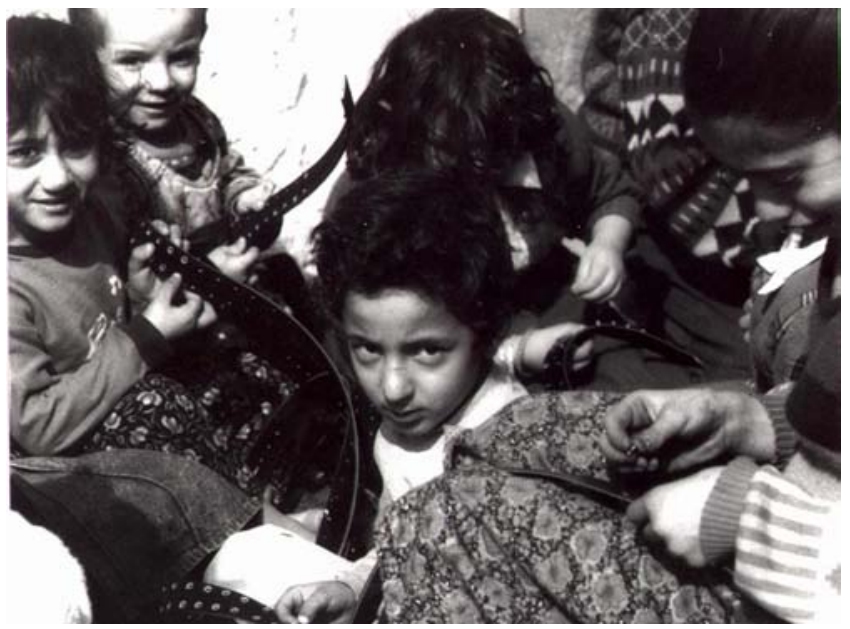

Fig. 4. Still from Look at me (1998) by Petek Berksoy.

\section{Fear: How Do You Evaluate Audiovisual Intelugence?}

A fundamental problem arose in the first weeks of the first class. Given our equipment constraints, I showed many kinds of low- and no-budget work. Yet all the time I was insisting on the thesis of the course: it is possible to make intellectual work in an audiovisual medium. One day was devoted to cameraless films: hand-drawn animations; films made by placing small objects on unexposed film and exposing them to light; Stan Brakhage's Mothlight (1963), which preserves actual objects between transparent film strips. After viewing these films, which most people liked very much, one student, Tim Auger, asked how they could be considered intellectual objects. His interrogation of the relationship between creativity and intelligence channeled a common but as yet unspoken anxiety in the class about how their work would be graded.

That night I couldn't sleep. Had I deceived the students? If Mothlight is intelligent, what is non-symbolic intelligence? I stayed up and wrote a letter to the class, which read in part:

Respected students,

This course has begun to pose an epistemological problem, which translates into a problem of how to grade your work. At the beginning of the course, and throughout it, I argued that intellectual work can be done in audiovisual media, that these media are as capable of intelligent expression as written forms are. This means that 
knowledge cannot always be expressed in symbolic terms. Yet in the course there was always a repressed question of how this intelligence can be evaluated.

This problem has come up increasingly in recent days as I talked with students about their projects and we struggled to express what kind of intellectual work was being done in, for example, a scratch ' $n$ ' paint film. I think the formulation that I offered at the beginning of the semester has been productive, as we (you) have been forced to think about your works as intellectual objects, smart movies. But I have also witnessed the restricting effect of my injunction to make smart work. Sometimes when people try to fit their projects into verbal formulas, this squeezes out the creative element of the project, resulting in dry work, "academic" in the worst sense. I want you to have enough freedom to explore your work even when what you're doing can't be translated into words. The words may come later; they may not.

The point for you is: you should try to explain your thought process verbally, as this will give your audience and your evaluator (me) some relatively objective evidence of the intellectual work that went into your project. This is the purpose of the one-page statement that accompanies your final project. But do not let this verbalizing destroy the creative germ of your work. It is my (and your audience's) job to see the non-verbal evidence of your intellectual work. Also, know that there is a relatively objective set of standards for evaluating your work, which is more or less the same as the set of standards for evaluating an essay. These standards also have an inescapably subjective element-just as they do when applied to essays.

The students received this letter with relief.

\section{Confusion: Does Intellectual Mean Critical? Does Critical Mean Experimental?}

Despite this system of evaluation, a tension persisted about how the students' varied interests would fare under the scrutiny of a teacher, me, who was especially interested in experimental work. Their concern raised an interesting critique of my modernist assumption that work can only be "smart" if it somehow reflects upon its own form. Intelligent content in a conventional form would not receive top grades.

I extricated myself from this dilemma by shifting the terms of the discussion. We were working with no to minuscule budgets, and that this would make it impossible to produce conventional work, whose demands, from shot-reverse shot structure to decent lighting, were just too expensive. If they managed to produce conventional narratives, or documentaries, within these constraints, they were effectively experimenting with the medium and would be rewarded. 
My feint worked. Almost invariably students chose to work within the forms I'd suggested that made a virtue of technological constraints. Their projects poured out as single-shot films, in-camera edited videos, videos produced entirely from appropriated images, hand-drawn animations, photo-text pieces, screenplays (where any number of cars could be blown up, at no cost) and other cheap, creative forms. Even a conventional story, told through these forms, became thrilling and satisfying. Aileen Mani and Gavin McKercher made a single-shot Blair Witch style horror film, in which the camera-operator protagonist, searching with a friend for a reported killer, ends up being murdered on camera by her colleague. Christina Walkinshaw, a stand-up comic, made an in-camera-edited story, illustrated with small props in the style of Sadie Benning, about getting food poisoning from a Wendy's chicken sandwich. Her hilarious, fast-talking voice-over narrative came on an accompanying audio cassette.

Almost always the students transformed the critical models I offered. The single-shot video assignment combined a particular cheap approach (no crew and editing required) with a particular intellectual practice (the intimate or confrontational personal video typical of early 1970s work). In one project it underwent a sort of European deconstruction. Damir Isailovic, one of the Serbian students, sits behind a table on the right side of the frame, addressing the stationary camera: "I have to make this video for class. It should be-spontaneous. It should be-intimate. Well I don't know about that but I can act a little: 'You talking to me?"' He begins to blindfold himself with an orange scarf, which happens to be the only spot of color in the shot. On the left side of the frame, up from behind the table comes Christine Kunze, the exchange student from Germany. She pulls off Damir's blindfold. "What is this foolishness?" Then she reminds him that, with the equipment shortage, they have to share cameras and so they each get 3 minutes and his time is up. They argue, and finally agree to do a synchronized swimming performance for the camera. The shot, and the video, ends with only their legs visible, bicycling up from the bottom of the frame.

This was a great piece because it worked within the formal constraints of the assignment while questioning its criteria. Is it fair to configure the form to the equipment constraint? Why should their style be like 1970s feminist video art just because the form is the same? I saw Damir and Christine's work as a critique of the (North) American fetish for spontaneity and culture of confession, made possible by their cultural vantage points. Yet the performance also 
had a life of its own, developing and unraveling until, despite their criticisms, they were waving their legs in the air.

Another time, a debate about the ethics of appropriating existing sounds and images turned hostile. To resolve it, the class and I collectively produced a video on "the things we should not steal." We explored the consequences of appropriation by doing it, rather than devising principles. We were pleased enough with the result to make a second, better structured collective tape, on the theme of "things we fear". Perhaps working together made it easier for us individually to confront our demons. Things we Fear was a successful work: hot, tight, and really scary.

\section{The Place of the Audiovisual in the University of Excellence}

As universities become indistinguishable from corporations, Readings argues, both the universities of Reason and of Culture have been supplanted by the University of Excellence. Empty of content, it easily absorbs critical and even "radical" thinking as simple commodities. "Audiovisual Practice" aimed to be critical, using audiovisual means, at a point in the history of the Western university when criticism had lost its disruptive capacity. The University of Reason that the course attempted to redefine had long since bitten the dust. A "Kantian nostalgia" 15 animates debates like ours in the class over the politics of appropriation: their content doesn't matter, as long as they are "excellent." In this regard we can understand the new influx of programs in visual culture, a combination of deracinated art history, cinema studies, and "theory," as uneasy attempts to maintain the intellectual capacity of the disciplines while extracting additional profit from them. Stephen Melville suggests that such programs mediate between the universities of Culture and of Excellence: "perhaps as a last resistance of the former to the latter, perhaps as an appropriation by the latter of what remains of the former." 16

Readings suggests that the recourse for teachers and students who don't want to adhere to the standards of a contentless "excellence" cannot be a return to the fallen truths of reason, culture, communication, or professional excellence. The ruined university is at best a site of obligation and ethical practice,

15. Bill Readings, The University in Ruins, p. 122.

16. Stephen Melville, "Art History, Visual Culture, and the University" in the "Visual Culture Questionnnaire," October, No. 76, summer 1996, p. 25-70. 
answerable not to truth but to justice. ${ }^{17}$ Thus in introducing audiovisual media in the university as intellectual media, it is important to distinguish their status as commodities from their capacity for-not criticism, but Thought.

A problem with the theory of multiple intelligences is that, once they can be quantified, they can be rewarded. And of course students want marketable skills too. Thus a final tension that the course witnessed, between its stated aim of cultivating audiovisual intelligence and the goal of many of the students to get into film school. Fortunately, the lack of equipment made it impossible for "A/V" to be a pre-professional course. However, many students needed work for their portfolios, and recommendation letters. I wrote the letters, but I was torn because the class did not prepare them for a career; their projects might even work against them in portfolios. "Audiovisual Practice" taught the not-so-marketable skill of working intellectually in nonverbal forms, and I defended this against the need for marketable products.

One of the goals of the course was to slow down the process whereby experience is translated into signification, signification is translated into communication, and communication is commodified. At each of these steps local experience is generalized, made discursive, made available to more people. This process, especially its first two steps, are the stuff of human communication. But it necessarily attenuates the original experience and renders it vulnerable to corruption. The experience is often valuable in inverse proportion to its communicability and commodifiability. For these reasons I wanted to thicken and slow the space of communication. In an era when symbolic meaning is quickly translated into capital, such a deceleration of communication is critical and creative.

Thus for example, while one of our earliest exercises in the class was to analyze Cindy Sherman's Untitled Film Stills (1977-1980) and observe how every aspect of composition, lighting, gesture, etc. was amenable to discursive explanation, still I encouraged students to make work that could not be entirely translated into words. Sound, too, arrives on a raft of received meanings or connotations, as our exercises in combining existing images with new sound tracks made clear. These exercises made clear the richness of audiovisual sign systems and the importance of controlling them in order to convey specific meanings. But beyond that, I wanted students to pursue affect, or embodied

17. Bill Readings, The University in Ruins, p. 154. 
meaning not easily translated into instrumental language. Poetry, too, would have had this effect.

Writing of a surprising moment in a video interview of Holocaust survivor, Roger Simon argues that video documentary invokes the phenomenological ethics of "being-with." ${ }^{18}$ Video is pedagogically rich because its "supplementary" quality doesn't expand or confirm meaning, he argues, but disrupts it. ${ }^{19}$ Similarly, the most powerful moments in the course-aesthetically, politically, pedagogically-were when the audiovisual objects connected with our bodies or connected us to each other. ${ }^{20}$ Moments of shared embodiment gave us a sense of mutual responsibility, tested, for example, by Things We Shouldn't Steal. For the assignment to make a surveillance project in the style of Sophie Calle, Justin Orfus showed a video shot in the privacy of his bedroom: he's playing air guitar shirtless, jumping on his bed, and then "realizes" with a sense of betrayal that his boyish jouissance is being recorded by a video camera. In Speak Up! Mami Sasaki, who hadn't said a word in class all semester, illustrated her sense of helplessness trying to speak English with images like a pencil bouncing down flights of stairs. Long Dô started doing performances where he would arrive late to class (mine and others'), walking on crutches and holding a big soft drink. He would trip and fall spectacularly, spilling the drink all over the floor, and check the reactions of professor and fellow students.

It should be clear that what I am critical of in the above is not language itself, but the instrumentality that accompanies "transparent" forms of communication. Once quantified, meaning translates into value, which can be translated into other systems, such as grades or money. To some degree this meaning comes at the expense of being: to be valued because one's "work" translates easily into the world of quantified meaning, instead of to linger on the threshold of value. Lingering allows us to question what is valued and to decide how and

18. Roger I. Simon, "The Audio-Visual Supplement of Holocaust Survivor Video Testimony," [unpublished manuscript], Toronto, University of Toronto Ontario Institute for Studies in Education, p. 14.

19. Roger I. Simon, "The Audio-Visual Supplement of Holocaust Survivor Video Testimony," p. 5.

20. Every work made in the class, even elaborate fictions and dry conceptual works, was a documentary of its own making by someone among us. This was true of many of the works we viewed as well. 
whether to enter into the systems of value production. Of course, my students were not schizophrenic fountains of inchoate being. Like most people, they came from clichés and they produced clichés: the film noir, the moralistic documentary, the Hallmark advertisement. Awakening, Benjamin writes (appropriating Proust) is the "supremely dialectical point of rupture." ${ }^{21}$ As we awakened from clichés, new things emerged: affective, disturbing events, a sense of newness and strangeness; the possibility of thought.

Our disputes in class - over experimentation, over appropriation, over collaboration-showed that students didn't necessarily share my specific political goals. The overtly "political" work produced in the course was often the most clichéd and smelled of reaction or of "this is what the teacher wants." But the works that appeared "apolitical" told much about the yearning of their young makers; they held open that yearning without providing a solution. They enjoined the viewer to share experiences that were ultra-local-getting through food poisoning, a skateboard accident, a broken heart-not "political" in the large sense. Their appeal was not moral, but ethical: they elicited a witnessing, a shared embodiment.

Ursula Beben's The Woman in This Picture was an ephemeral work for an audience of one: a stack of fading family photos and a poem on a Walkman. In the snapshots, taken over the course of about 15 years, Ursula's mother invariably presents the camera with a look than can be nothing but desperation even as her mouth is stretched in a smile, her eyes black holes among the Thanksgiving revelers. The poem tells of a woman who intends to leave her family, to escape with her lover, but she is cooking a pot roast and the heavy smell of frying onions pulls her down. She stays. Listening privately to the poem and looking at these photographs of Ursula's mother, I felt her bravery and compassion in a way that was almost unbearable.

"Audiovisual Practice" lingered in the ruins of the university. It was an academic mongrel, a mutt. By nature of its intolerable location within the institution, its refusal (more or less) to provide marketable skills, and its working with the soft material of images, bodies, and events, the course achieved something significant. It opened up a space for thinking, for asking what and how 
it is important to think. The course made some room for the subtle intelligences, embodied and emotional, that are rarely expressed in an academic context. It did not try to draw profit from the knowledge's that resulted, but merely let them move, like fronds of seaweed under water. The course gave expression to life. What that life would do was beyond its control. ${ }^{22}$

22. I extend my warmest appreciation to André Loiselle, my colleague in the School for Studies of Art and Culture at Carleton University in Ottawa, who even when I gave up believed in the intellectual potential of non-written forms, and in our students. "Audiovisual Practice" is currently in the able hands of James Missen. 